\title{
Tin as an Effective Doping Agent into ZnO for the Improved Photodegradation of Rhodamine B
}

\author{
Aqeel Ahmed Shah ${ }^{1}$, Muhammad Ali Bhatti ${ }^{2}$, Ali Dad Chandio ${ }^{1}$, Khalida Faryal Almani², \\ Mazhar Ali Abbasi ${ }^{5}$, Adeel Liaquat Bhatti ${ }^{5}$, Abdul Qayoom Mugheri ${ }^{4}$, Magnus Willander ${ }^{3}$, \\ Omer Nour ${ }^{3}$, Baradi Waryani ${ }^{6}$, Aneela Tahira ${ }^{3}$, and Zafar Hussain Ibupoto ${ }^{4, *}$ \\ ${ }^{1}$ NED University of Engineering and Technology Karachi, Sindh 75270, Pakistan \\ ${ }^{2}$ Department of Environmental Sciences University of Sindh Jamshoro, Sindh 76080, Pakistan \\ ${ }^{3}$ Department of Science and Technology, Campus Norrkoping, Linkoping University, SE-60174 Norrkoping, Sweden \\ ${ }^{4}$ Dr. M. A Kazi Institute of Chemistry University of Sindh Jamshoro, Sindh 76080, Pakistan \\ 5 Institute of Physics University of Sindh Jamshoro, Sindh 76080, Pakistan \\ ${ }^{6}$ Department of Fresh Water Biology and Fisheries University of Sindh Jamshoro, Sindh 76080, Pakistan
}

\begin{abstract}
We have fabricated $\mathrm{ZnO}$ nano rods by hydrothermal method and successively doped them with tin (Sn) using different concentrations of $25,50,75$ and $100 \mathrm{mg}$ of tin chloride. XRD of the fabricated structures showed that $\mathrm{ZnO}$ possess hexagonal wurtzite phase. Scanning electron microscopy (SEM) was used to explore the morphology and it shows nanorod like morphology for all samples and no considerable change in the structural features were found. The dimension of nanorod is 200 to $300 \mathrm{~nm}$. The doped materials were then investigated for their photo catalytic degradation of environmental pollutant Rhodamine B. The performance of doped $\mathrm{ZnO}$ is compared with the pristine $\mathrm{ZnO}$. Scanning electron microscopy (SEM) was used to explore the morphology and it shows nanorod like morphology for all samples and no considerable change in the structural features were found. The dimension of nanorod is 200 to $300 \mathrm{~nm}$. XRD of the fabricated structures showed that $\mathrm{ZnO}$ possess hexagonal wurtzite phase. Photo catalytic activity of rhodamine $\mathrm{B}$ was investigated under UV light and a maximum degradation efficiency of $85 \%$ was obtained. The optical property reveals the reduction in band gap of upto $17.14 \%$ for $100 \mathrm{mg} \mathrm{Sn}$ doped $\mathrm{ZnO}$. The degradation is followed by the pseudo order kinetics. The produced results are unique in terms of facile synthesis of $\mathrm{Sn}$ doped $\mathrm{ZnO}$ and excellent photo degradation efficiency, therefore these materials can be used for other environmental applications.
\end{abstract}

Keywords: Tin Doped ZnO, Rhodamine B, Photodegradation, Aqueous Solution.

\section{INTRODUCTION}

Water pollution has become a serious environmental issue like rivers get contaminated and impart adverse effects to aquatic life and living beings due to its toxicity. Industrial effluents are main source of water pollution. Specifically, organic dyes and their effluents from various industries [1-3] like plastics, colorant, food and cosmetics [4-7] is major cause of water pollution. Rhodamine $\mathrm{B}$ $\left(\mathrm{C}_{28} \mathrm{H}_{31} \mathrm{ClN}_{2} \mathrm{O}_{3}\right)$ is amongst the dyes used in textile, food, and water tracing in order to track water for the determination of its treatment capabilities, food industry and textile

\footnotetext{
*Author to whom correspondence should be addressed.
}

industry for coloring and printing [8]. It is very harmful for living beings causing numerous diseases [9-13]. The removal of the dyes is therefore indispensable for cleaner water, environment and healthy society. Researchers have made numerous approaches for instance adsorption, flotation, chlorination, ozonation, chemical oxidation and coagulation to remove these kinds of contaminants from waste water [14-18]. But there are different issues with these approaches like some remain soluble in effluent [19-21], some are ineffective [22-24] while others leave unpleasant taste and odor [25] and they are costly [26]. Photo catalytic degradation in conjunction with nanostructured oxides materials is an environmental friendly alternative for the treatment of these dyes [27-28] and has become 
choice for the wide range of researchers [29-31] where photo catalysts are used to remove the pollutants in the presence of light source. $\mathrm{ZnO}$ is playing dominating role as photo catalysts [32-35] while compared to other catalysts like [36-37] due to its low cost, higher absorption efficiency than titania, easy to grow, high stability in thermal, chemical and physical environments [38-40] and is utilized in wide range of applications. Moreover, as it is a direct wide band gap material having $3.37 \mathrm{eV}$ of band gap it finds applications like in LEDs, laser diodes, photovoltaic, semiconductor heterojunction, transparent conductors, and so on [41-44]. Still the lower quantum efficiency of $\mathrm{ZnO}$ leads to faster recombination rate of charge carriers [45] which results in poor photo degradation efficiency. Moreover, the wide band gap of $\mathrm{ZnO}$ restrict its absorption of ultraviolet light only leading to decrease in photocatalytic efficiency in the visible region [46]. Also, in order to get maximum juice of solar spectrum the semiconductors should have smaller band gap [47]. Besides, band gap has crucial role to improve the physical properties of semiconductors [48-50] as well as increase the efficiency of photocatalysis. To resolve this issue doping is popular way to achieve the efficiency as well as to adjust the band gap [48-50]. Among various dopants like copper, silver, $\mathrm{Mn}, \mathrm{Co}, \mathrm{Eu}, \mathrm{Ce}, \mathrm{Gd}, \mathrm{La}, \mathrm{Ni}, \mathrm{Al}$ used by researchers [51-62]. Sn doped $\mathrm{ZnO}$ has gained much attention because it has good oxidation rate and can substitute into $\mathrm{Zn}$ lattice without any difficulty [63]. Rosaline Beura and coworkers [63]. reported $\mathrm{ZnO}$ doped with Tin for the removal of methyl Orange and were successful to decrease the band gap upto $3.16 \mathrm{eV}$ gaining a total of $1.25 \%$ reduction in band gap with good degradation efficiency of methyl orange. The same group again used $\mathrm{Sn}$ doping in $\mathrm{ZnO}-$ Graphene nano composite and got an improved reduction in band gap upto 8.97\%. [64] for the degradation of four different dyes. However, the band gap study for tin doped $\mathrm{ZnO}$ for the removal of rhodamine $\mathrm{B}$ is rarely investigated and remain successful to reduce band gap by $17.14 \%$.

We report a significant decrease in the band gap of $\mathrm{ZnO}$ from 3.5 to $2.9 \mathrm{eV}$ which is $17.14 \%$ with addition of $100 \mathrm{mg}$ of tin in $\mathrm{ZnO}$. Moreover, the addition of tin reduced band gap from $3.5 \mathrm{eV}$ of pristine $\mathrm{ZnO}$ to 3.39 , $3.23,3.06$ and $2.90 \mathrm{eV}$ for the $25,50,75$ and $100 \mathrm{mg}$ of tin dopant respectively. This study shows that the doping has remarkable effect upon the $\mathrm{ZnO}$ band gap. The efficiency of degradation of rhodamine $\mathrm{B}$ was found to be increasing up to $85 \%$ with reduction of band gap and increase in doping concentration.

\section{MATERIALS AND METHODS}

\subsection{Materials}

Tin (II) chloride $\left(\mathrm{SnCl}_{2}, \mathrm{M}=189.6\right)$, zinc acetatedihydrate $\left(\mathrm{ZnC}_{4} \mathrm{H}_{6} \mathrm{O}_{4}\right)$, solution of ammonia (25\%) were obtained from Merck. Rhodamine B, and ethanol

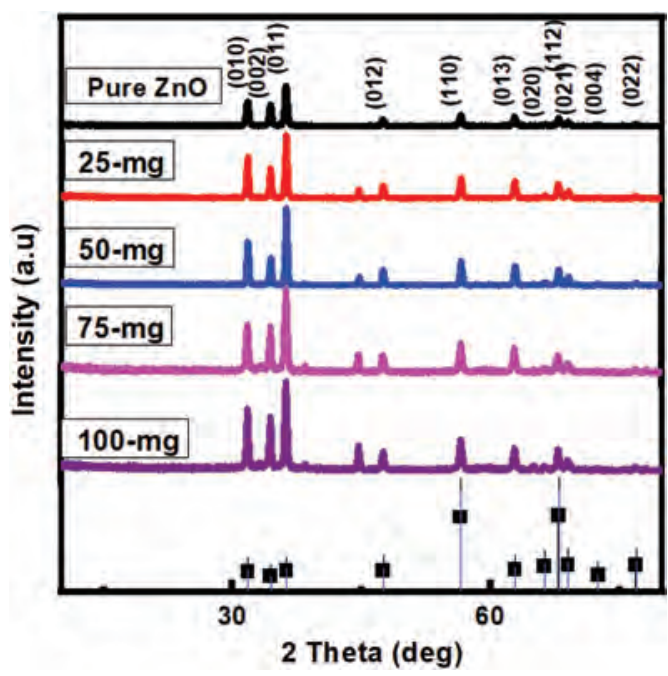

Figure 1. $\mathrm{XRD}$ results of pristine $\mathrm{ZnO}$ versus doped $\mathrm{ZnO}$ with 25, 50, 75 and $100 \mathrm{mg}$ of tin doping concentration.

were obtained from Sigma-Aldrich and were used as received condition. The deionized water was used in all experiments.

\subsection{Synthesis of $\mathrm{Sn}$ Doped $\mathrm{ZnO}$ Nanostructures}

We used precipitation process for the synthesis of $\mathrm{ZnO}$ nanostructures and doping with Sn. We used a zinc acetate di-hydrate and 25\% ammonia as precursors. At first different contents of tin ranging from 25, 50, 75 and $100 \mathrm{mg}$ were dispersed in ethanol $(5 \mathrm{~mL})$ and then sonicated for 30 minutes. Zinc acetate di-hydrate $(2.22 \mathrm{~g})$ was dissolved into $100 \mathrm{~mL}$ of the deionized water then $25 \%$ ammonia $(5 \mathrm{~mL})$ was added to zinc precursor. We took five beakers having zinc acetate di-hydrate as well as ammonia. Four of them with individual concentration of $\mathrm{SnCl}_{2}$ ranging from 25, 50, 75 and $100 \mathrm{mg}$ of $\mathrm{SnCl}_{2}$ were added in $5 \mathrm{~mL}$

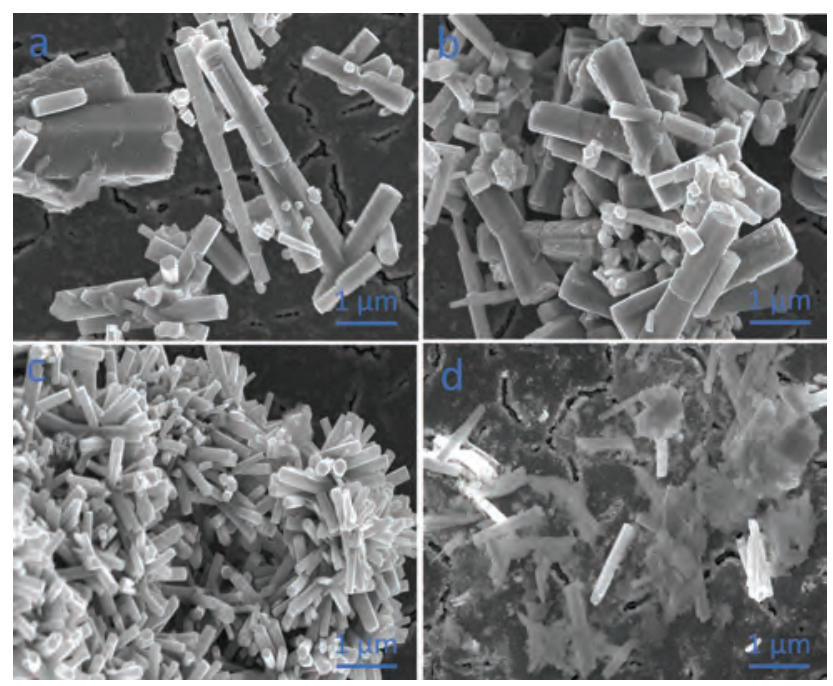

Figure 2. SEM images of $25 \mathrm{mg}$ doped $\mathrm{ZnO}$ nano rods (a) and $50 \mathrm{mg}$ doped $\mathrm{ZnO}$ nano rods (b), $75 \mathrm{mg}$ doped $\mathrm{ZnO}$ (c) $100 \mathrm{mg}$ doped $\mathrm{ZnO}$ (d). 


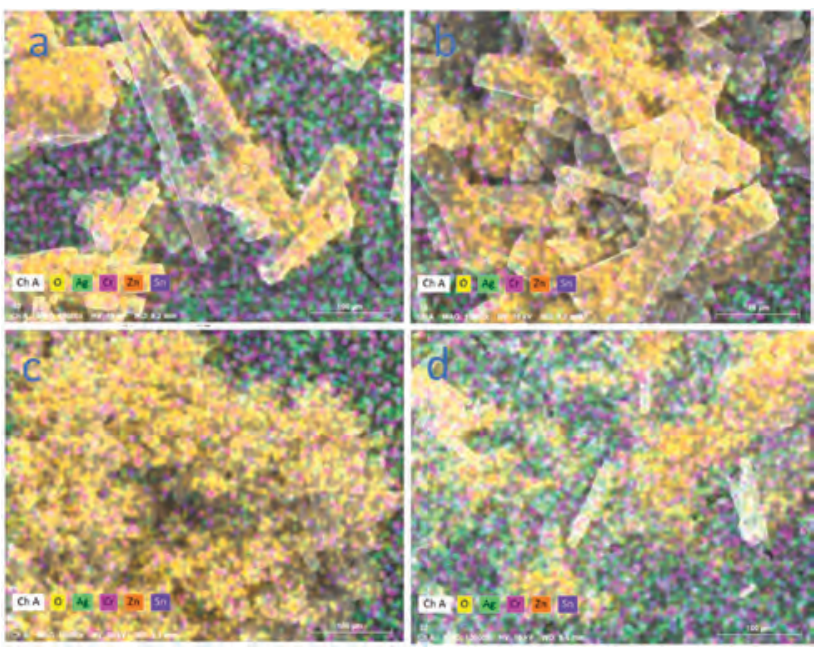

Figure 3. Elemental mapping for $25 \mathrm{mg}$ doped $\mathrm{ZnO}$ nano rods (a) and $50 \mathrm{mg}$ doped $\mathrm{ZnO}$ nano rods (b), $75 \mathrm{mg}$ doped $\mathrm{ZnO}$ (c) $100 \mathrm{mg}$ doped $\mathrm{ZnO}(\mathrm{d})$.

of ethanol and thereby were labeled as e 1, 2, 3, and 4 samples respectively. Fifth beaker with concentration of zinc acetate di-hydrate as well as ammonia was labeled as pristine sample. Aluminum foil was applied to cover the beakers to restrict the evaporation of growth solution. The oven temperature was set and heated at $90{ }^{\circ} \mathrm{C}$ followed by placement of beakers into the oven for holding time of 5 hours. After holding time passed the beakers were removed from oven. A white product was seemed in each beaker. The white product, which was separated by filtering, drying and was ready for characterization.

The morphological analysis of tin doped nanostructures were done by scanning Electron microscope at an accelerating voltage of $3 \mathrm{kV}$, composition was estimated by energy dispersive spectroscopy (EDS), crystal structure was studied by X-ray diffraction at applied conditions of $\mathrm{CuK} \alpha$ radiation $(\lambda=1.5418 \AA)$ at a generator voltage of $45 \mathrm{kV}$ and a current of $45 \mathrm{~mA}$., while the optical properties were obtained by Perkins UV-vis spectrophotometer.

Rhodamine B was considered to degrade owing to its importance using $\mathrm{ZnO}$ samples in aqueous solution. A Rhodamine B concentration of $0.0001 \mathrm{M}$ was made in the deionized water followed by the addition of $10 \mathrm{mg}$ of each material in separate flasks. Then solutions were stirred in ultrasonic bath for 30 to 40 mints in order to achieve equilibrium for adsorption and desorption conditions. Then dye containing photo catalysts was illuminated with UV light of wavelength $365 \mathrm{~nm}$ with a power of 10 Watt for activation of catalysts and used for different time intervals. The dye concentration before to the phtocatalytic process was estimated from UV-visible (a)

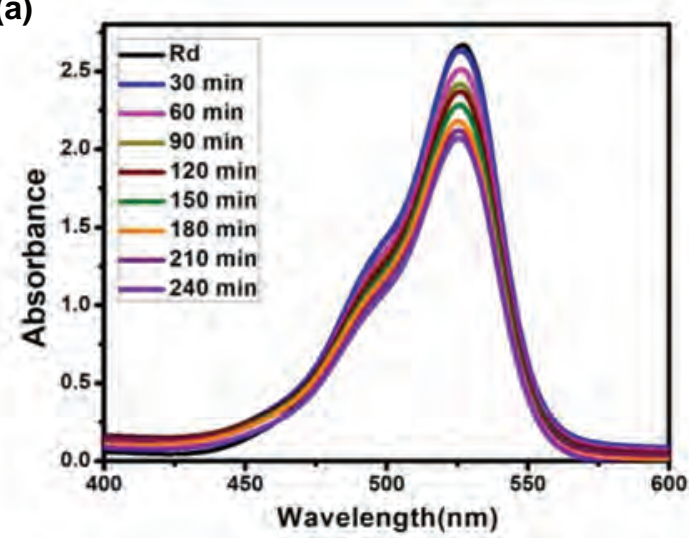

(c)

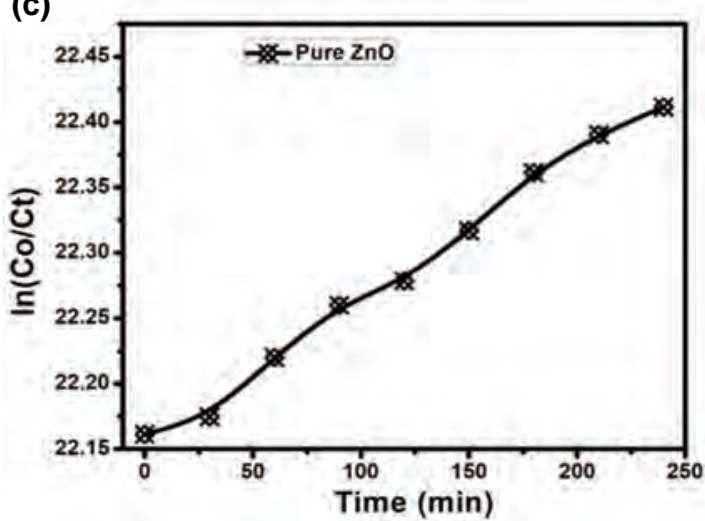

(b)

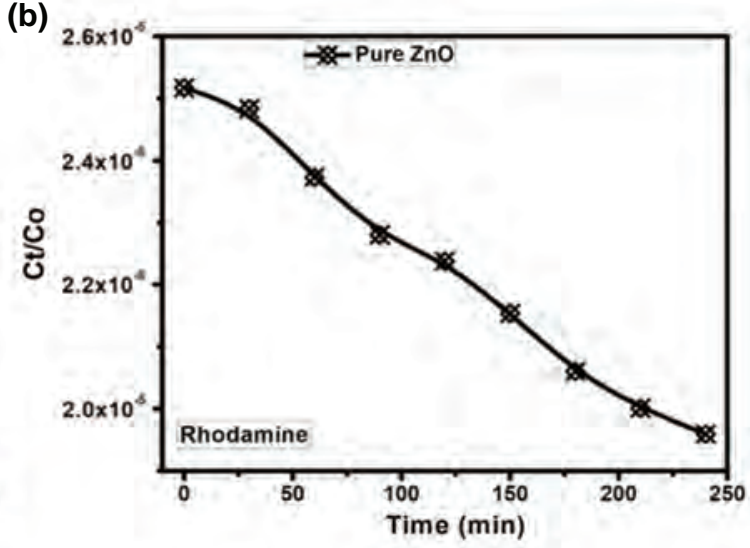

(d)

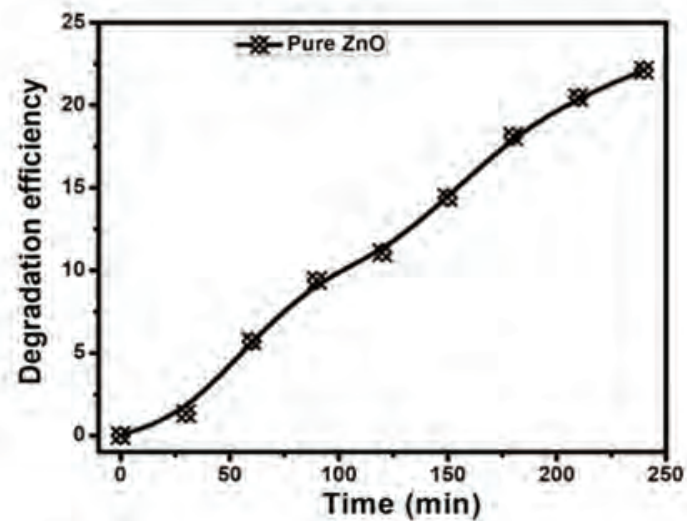

Figure 4. UV-visible spectra of pristine $\mathrm{ZnO}(\mathrm{a}, \mathrm{b})$ reaction kinetics (c) kinetics of photo degradation of Rhodamine $\mathrm{B}$ i.e., $\ln \left(C_{0} / C_{t}\right)$ versus time (d) photo degradation efficiency of pure $\mathrm{ZnO}$. 
absorption spectrum. The degradation performance of tin doped $\mathrm{ZnO}$ was demonstrated via \% percent degradation of Rhodamine and was estimated from the below Eq. (1).

$$
\% \mathrm{CR}=\frac{C_{0}-C_{t}}{C_{0}} \times 100
$$

The $C_{0}$ and $C_{t}$ are corresponded to the initial concentrations of Rhodamine $(\mathrm{mg} / \mathrm{L})$ and after a time interval of $(t)$ during UV light illumination.

\section{RESULTS AND DISCUSSION}

\subsection{XRD}

Pristine $\mathrm{ZnO}$ and doped $\mathrm{ZnO}$ with various concentrations of tin were investigated by XRD (see Fig. 1). The set of peaks at positions of $31.737^{\circ}, 34.420^{\circ}, 36.225^{\circ}, 47.515^{\circ}$, $56.536^{\circ}, 62.836^{\circ}, 66.304^{\circ}, 67.893^{\circ}, 69.015^{\circ}, 72.561^{\circ}$ and $76.891^{\circ}$ was observed with respective planes of $\mathrm{ZnO}$ corresponding to (010), (002), (011), (012), (110), (013), (020), (112), (021), (004) and (022) crystal planes respectively. For the determination of crystal structure and phase analysis the obtained XRD results are in good similarity to the standard JCPDS card no. 96-900-4182. It was observed that the diffraction patterns showed no remarkable variations in the intensity while compared to pristine $\mathrm{ZnO}$.

\subsection{SEM and EDS}

The morphological analysis of the samples was investigated by scanning electron microscope. It was clearly seen that the nano rods were successively formed and there were no big changes observed even after by the addition of tin doping concentrations. As shown in Figure 2. The doped samples of $\mathrm{ZnO}$ with tin with low concentration are bigger in size as can be visualized from the Figures 2(a), (b). The size of nanorods is few microns in length with an average diameter of 200-300 nm. It can also be observed that at higher concentration of tin chloride the nanorods started to become thinner as seen in Figures 2(c), (d).

The elemental mapping spectra are illustrated in Figures 3(a)-(d) for tin doped $\mathrm{ZnO}$ which ensures the presence of $\mathrm{Sn}$, oxygen and $\mathrm{Zn}$ as main elements. Whereas $\mathrm{Cr}$ and Ag were also seen as impurity from the substrate.
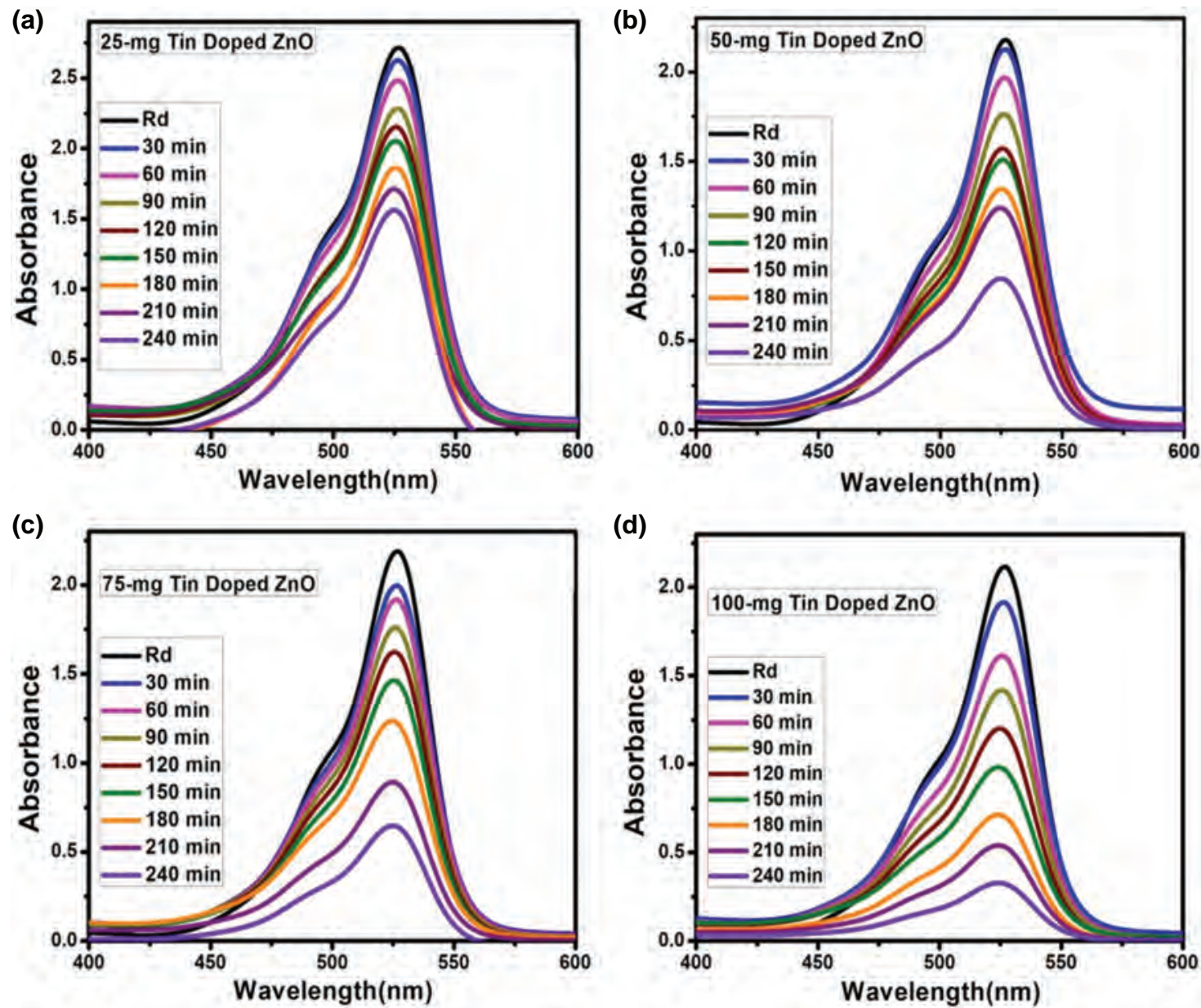

Figure 5. UV-visible spectra for different tin concentrations such as 25, 50, 75, and $100 \mathrm{mg}$ in $\mathrm{ZnO}$ nanorods for removal of Rhodamine $\mathrm{B}$ at eight-time variations from 30-240 minutes at each 30 minutes intervals. 


\subsection{UV-Visible Spectra}

\subsubsection{Pristine $\mathrm{ZnO}$}

The nanostructures including pure $\mathrm{ZnO}$ and doped $\mathrm{ZO}$ were used to treat Rhodamine B to check its photo degradation in aqueous solution under UV light at different time intervals. The results for the pristine $\mathrm{ZnO}$ are depicted in Figure 4 whereby Figure 4(a) shows UV-visible absorption spectra. $C_{t} / C_{0}$ curve corresponds to the undoped $\mathrm{ZnO}$ for degradation of Rhodamine under exposure of UV light Figure 4(b). Figure 4(c) shows kinetics of degradation of rhodamine and efficiency of degradation is depicted in Figure 4(d) for pristine $\mathrm{ZnO}$ the maximum degradation efficiency was observed to be $22 \%$. The poor performance of pristine $\mathrm{ZnO}$ can be added to the fast charge recombination rate and large energy band gap. Further photo degradation kinetics was found to be pseudo order kinetically as can be seen in the Figures 4(b), (c).

\subsubsection{Sn-Doped $\mathrm{ZnO}$}

UV-vis absorption results for the tin doping in $\mathrm{ZnO}$ nanorods with varying concentrations are shown in Figure 5. At first $10 \mathrm{mg}$ of each of the 25. 50, 75 and $100 \mathrm{mg}$ tin doped
ZnO samples were added to Rhodamine dye solution under UV exposure for the time irradiation of 30 to 240 minutes with 30 minutes of time interval each for getting photo degradation of Rhodamine B Figures 5(a)-(d).

With addition of dopant impurity of tin $(25,50,75$ and $100 \mathrm{mg}$ ) the degradation efficiency was seemed to be increasing. In comparison the maximum degradation of $22 \%$ for undoped $\mathrm{ZnO}$ was observed and with increase in doping concentration and increase in the efficiency of upto $85 \%$ was achieved for doping concentration of $100 \mathrm{mg}$ of tin, that shows that there is a remarkable improvement in photo degradation of Rhodamine by doping $\mathrm{ZnO}$ with tin.

Figure 6(a) shows $C_{t} / C_{0}$ curve for $\mathrm{Sn}$-doped $\mathrm{ZnO}$ for Rhodamine dye under UV light exposure. Degradation kinetics follows pseudo-first-order rate Figure 6(b). The photo degradation efficiency for doped $\mathrm{ZnO}$ is given in Figure 6(c) that clearly shows that by increasing doping concentration of $\mathrm{Sn}$ results in increasing the degradation efficiency. Doping of 25, 50, 75 and $100 \mathrm{mg}$ of $\mathrm{Sn}$ in $\mathrm{ZnO}$ resulted in increase in degradation efficiency of $43,62,70$ and $85 \%$ respectively. It was observed that a maximum
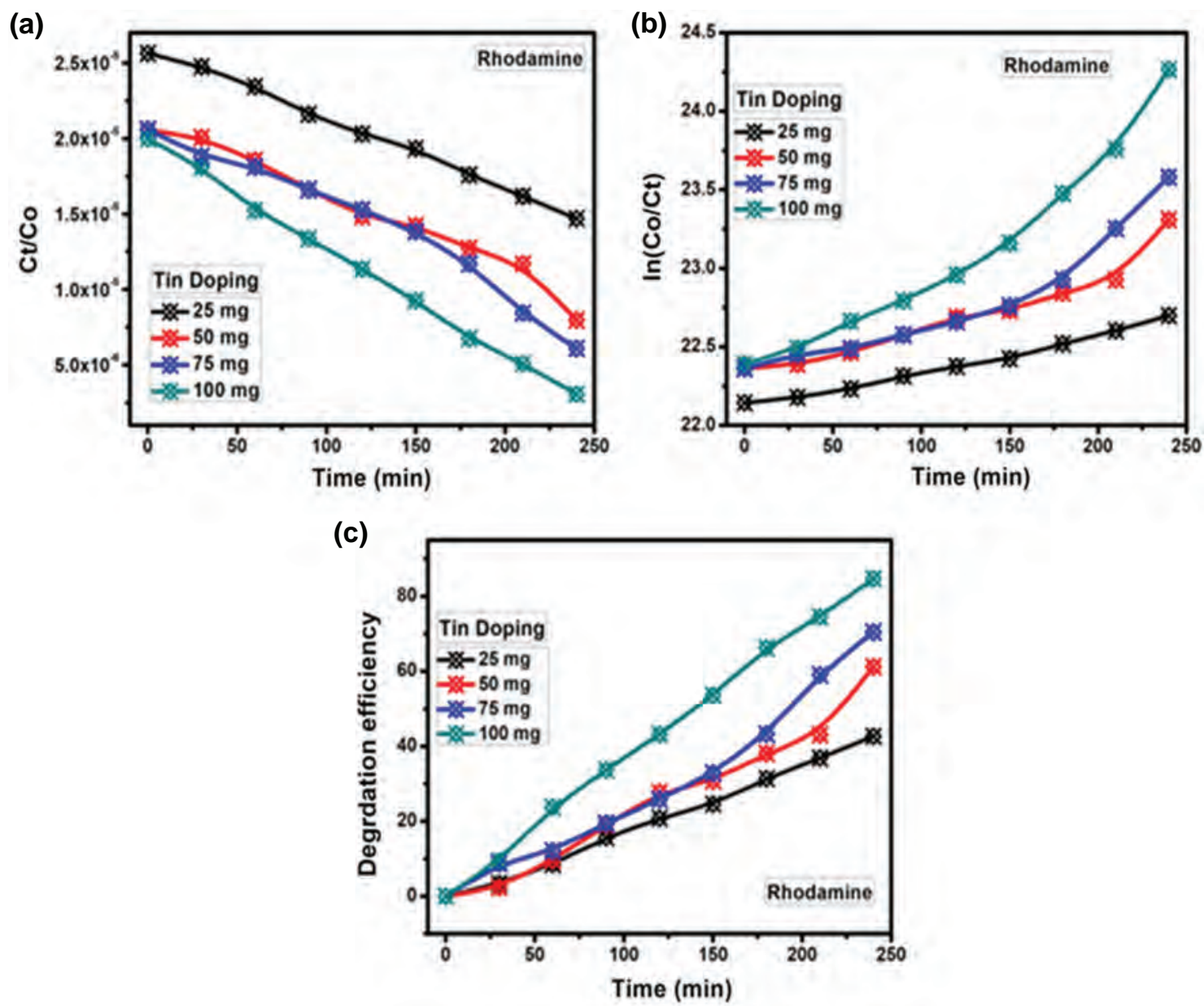

Figure 6. UV-Vis results for tin doped $\mathrm{ZnO}$ nano rods for Rhodamine $\mathrm{B}$ degradation (a) reaction kinetics Plot $C t / C_{0}$ versus time (b) degradation kinetics curve for $\ln \left(C_{0} / C t\right)$ versus time (c) photo degradation efficiency. 
of $85 \%$ efficiency for degradation of Rhodamine B was achieved by $100 \mathrm{mg}$ doping of tin. The favorable photodegradation efficiency can be attributed to the decrease in recombination rate and increase in the charge separation of charge carriers which are further supported by the decrease in the optical band gap of tin doped $\mathrm{ZnO}$ samples.

On UV light irradiating of $\mathrm{SnO}_{2}$-doped $\mathrm{ZnO}$ nanocomposites, the electrons and holes were produced in $\mathrm{CB}$ and VB of $\mathrm{SnO}_{2}$ and $\mathrm{ZnO}$. Subsequently the $\mathrm{CB}$ of $\mathrm{ZnO}$ lies above the $\mathrm{CB}$ of $\mathrm{SnO}_{2}$, therefore, the photogenerated electrons produced get shifted from the $\mathrm{CB}$ of $\mathrm{ZnO}$ to that of $\mathrm{SnO}_{2}$. On opposing, the holes get shifted from the VB of $\mathrm{SnO}_{2}$ to $\mathrm{VB}$ of $\mathrm{ZnO}$. In addition, on adsorption of $\mathrm{O}_{2}$ on the surface of photocatalyst, an active oxygen species $\left(\mathrm{O}_{2}^{--}\right.$, a radical anion $)$formed due to the electrons present in the $\mathrm{CB}$ of $\mathrm{SnO}_{2}$ which on protonation formed $\mathrm{OOH}$ radical. At the end, $\mathrm{OH}$ radicals generated which are accountable for the degradation of complex dye molecules into smaller compounds. On the other hand, $h+$ also react with - $\mathrm{OH}$ and gives to the formation of ${ }^{\circ} \mathrm{OH}$ present in the $\mathrm{VB}$ of $\mathrm{ZnO}$. On the surface of the photocatalyst, the general reactions can be described as below [65]:

$$
\begin{gathered}
\mathrm{SnO}_{2}+h v \rightarrow e_{\mathrm{cb}}^{-}+h_{\mathrm{vb}}^{+} \\
\mathrm{ZnO}+h v \rightarrow e_{\mathrm{cb}}^{-}+h_{\mathrm{vb}}^{+} \\
\left(\mathrm{SnO}_{2}\right) e^{-}+\mathrm{O}_{2} \rightarrow \mathrm{O}_{2}^{--} \\
\mathrm{O}_{2}^{--} h^{+} \rightarrow \cdot \mathrm{OOH} \\
2^{\cdot} \mathrm{OOH} \rightarrow \mathrm{H}_{2} \mathrm{O}_{2}+\mathrm{O}_{2} \\
\mathrm{H}_{2} \mathrm{O}_{2}+e^{-} \rightarrow \cdot \mathrm{OH}^{-}+{ }^{-} \mathrm{OH} \\
(\mathrm{ZnO}) h_{\mathrm{vb}}^{+}+{ }^{-} \mathrm{OH} \rightarrow \cdot \mathrm{OH} \\
\cdot \mathrm{OH}+\mathrm{Dye} \rightarrow \text { Simpler compounds }
\end{gathered}
$$

Therefore, $\left(\mathrm{O}_{2}^{\cdot-\cdot} \mathrm{OOH}\right.$ and $\left.\cdot \mathrm{OH}\right)$ active species of oxygen were engendered when the reactant molecule get adsorbed on the surface of $\mathrm{SnO}_{2}$ doped $\mathrm{ZnO}$ nanoparticles. The degradation of dye is mainly due to these active species.

The photocatalysis mechanism can correlated to the optical band gap as it absorbs the photogenerated charge carriers via superficial crystal defects. Photocatalytic effect is attributed to the presence of $\mathrm{ZnO}$ itself and tin induction into it. The superior performance of tin doped $\mathrm{ZnO}$ is connected to the varying conduction and valence band inside the semiconducting $\mathrm{ZnO}$. The decreases in optical band gap offers the change in the energy states which uplift the charge separation using tin doped $\mathrm{ZnO}$ nanostructures. This further reduces the recombination of charge carriers and consequently superfast photodegradation efficiency is observed. During the illumination of UV light, the photo produced charge carriers are stimulating to $\mathrm{Sn}$ within $\mathrm{ZnO}$ which are playing a critical participation for the absorption of photo generated electrons with the provision of superoxide radicals. The high intensity of produced superoxide radicals further fosters the degradation process; thus, we have found an excellent $85 \%$ photodegradation efficiency.

\subsubsection{Effect of Tin Doping on Optical Ban Gap of $\mathrm{ZnO}$}

We also studied band gap effect as given Figures 7(a), (b). Figure 7(a), shows the normal UV-visible spectra for the different samples and Figure 7(b), shows Tauc plot for the calculation of band gap. Tauc, s plot gives the information about the direct and indirect band gap for a semiconducting material, we see a direct band for the doped and pure $\mathrm{ZnO}$ samples. Here band gap for the pristine $\mathrm{ZnO}$ was $3.5 \mathrm{ev}$ which was decreased with increase in tin content. We have achieved a total reduction in band gap of $17.14 \%$ that shows that doping enhances the reduction in band gap. The reduction of band gap with respect to increasing of tin concentration is shown in Table I. Therefore, increasing doping concentration of tin not only reduces band gap but it also increases degradation efficiency leading to that fact
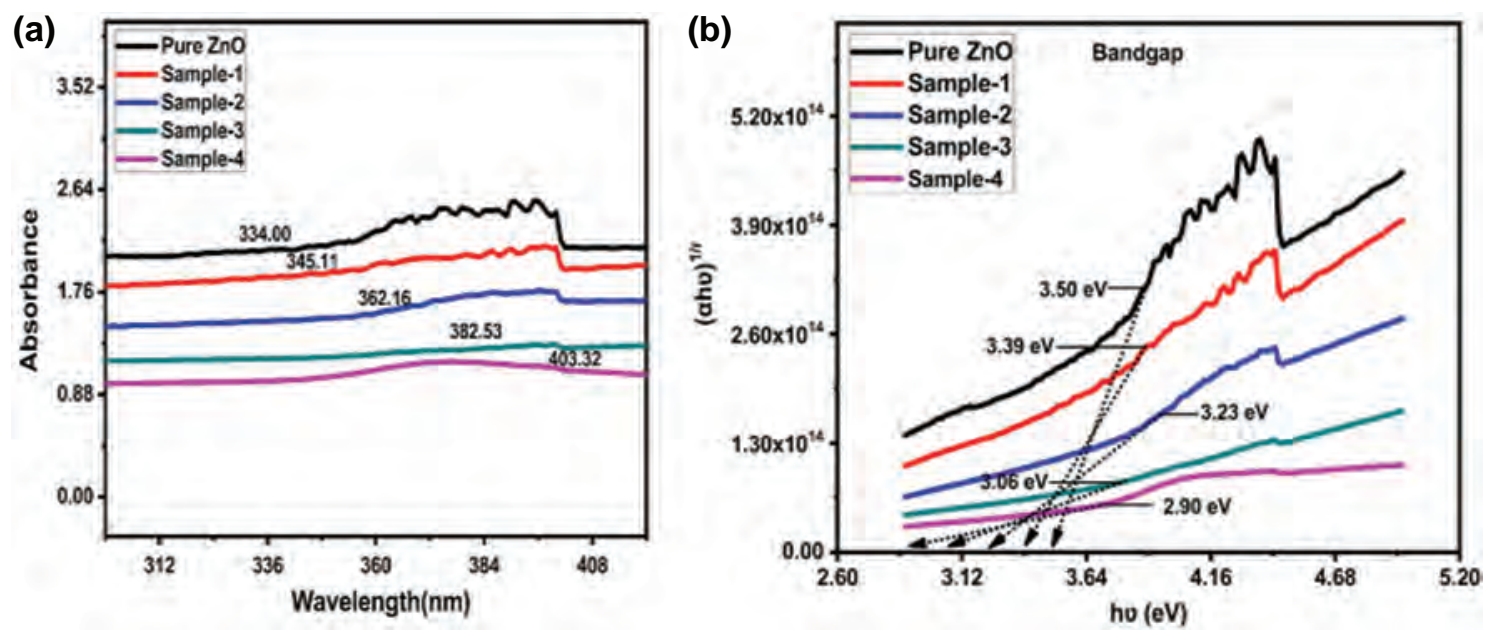

Figure 7. (a.) UV-visible absorption spectra for various Sn doped $\mathrm{ZnO}$ samples, (b) the estimation of optical band gap of various ZnO samples. 
Table I. Band gap for undoped versus Sn-doped $\mathrm{ZnO}$.

\begin{tabular}{lcc}
\hline Sample & Cut off wavelength & Band gap $(\mathrm{eV})$ \\
\hline Pristine ZnO & 334.0 & 3.5 \\
$25 \mathrm{mg}$ tin doped & 345.11 & 3.39 \\
$50 \mathrm{mg}$ tin doped & 362.16 & 3.23 \\
$75 \mathrm{mg}$ tin doped & 382.53 & 3.06 \\
$100 \mathrm{mg}$ tin doped & 403.32 & 2.90 \\
\hline
\end{tabular}

that band gap has linear relationship with the degradation efficiency.

\section{CONCLUSION}

We successively obtained Sn-doped $\mathrm{ZnO}$ nanorods by hydrothermal method. The SEM and XRD results confirmed that there were no significant changes in the morphology of doped structures. The photodegradation efficiency was increased with increased in doping concentration. The maximum degradation efficiency of $85 \%$ was achieved for degradation of Rhodamine B. The optical study showed significant decrease in band gap with respect to increase in doping content of tin and maximum reduction of up to $17.14 \%$ was achieved which shows that tin plays remarkable role on $\mathrm{ZnO}$ band gap and the structures are suitable to be applied for waste water treatment. The used strategy for Rhodamine B degradation is simple, low cost, environment friendly and uses earth abundant and nonprecious materials, therefore scale up production of materials for energy and other environmental applications.

\section{References and Notes}

1. Ko, F.H., Lo, Y.C., Chang, J.Y., Guo, C. and Chen M., 2013. ZnO nanowires coated stainless steel meshes as hierarchical photocatalysts for catalytic photodegradation of four kinds of organic pollutants. Journal of Alloys and Compounds, 678, pp.137-146.

2. Tripathy, N., Ahmad, R., Eun, J.S., Ah, H.K., Hahn, Y.B. and Khang, G., 2014. Photocatalytic degradation of methyl orange dye by $\mathrm{ZnO}$ nanoneedle under UV irradiation. Materials Letters, 136, pp.171-174.

3. Han, F., Kambala, V.S.R., Srinivasan, M., Rajarathnam, D. and Naidu, R., 2009. Tailored titanium dioxide photocatalysts for the degradation of organic dyes in wastewater treatment: A review. Applied Catalysis A, 359, pp.25-40.

4. Wu, P., Jiang, L.Y., He, Z. and Song, Y., 2017. Treatment of metallurgical industry wastewater for organic contaminant removal in China: Status, challenges, and perspectives. Environ. Sci.: Water Res. Technol., 3, pp.1015-1031.

5. Huang, Z., Li, Y., Chen W., Shi, J., Zhang, N., Wang, X., Li, Z., Gao, L. and Zhang, Y., 2017. Modified bentonite adsorption of organic pollutants of dye wastewater. Materials Chemistry and Physics, 202, pp.266-276.

6. Kono, H., Ogasawara, K., Kusumoto, R., Oshima, K., Hashimoto, H. and Shimizu, Y., 2016. Cationic cellulose hydrogels cross-linked by poly(ethylene glycol): Preparation, molecular dynamics, and adsorption of anionic dyes. Carbohydrate Polymers, 152, pp.170-180

7. Allam, et al., 2011. Colorants the cosmetics for the pharmaceutical dosage forms. International Journal of Pharmacy and Pharmaceutical Sciences, 3, pp.13-21.

8. Richardson, S.D., Wilson, C.S. and Rusch, K.A., 2004. Use of rhodamine water tracer in the marshland upwelling system. Ground Water, 42(5), pp.678-688.
9. Cheng, Y.Y. and Tsai, T.H., 2016. A validated LC-MS/MS determination method for the illegal food additive rhodamine B: Applications of a pharmacokinetic study in rats. J. Pharmac. Biom. Analy., 125, pp.394-399.

10. Kornbrust, D. and Barfknecht, T, 1985. Testing of 24 food, drug, cosmetic, and fabric dyes in the in vitro and the in vivo/in vitro rat hepatocyte primary culture DNA repair assays. Environm. \& Mole. Mutagenes., 7.

11. Shimada, T., Yamazaki, H., Mimura, M., Inui, Y. and Guengerich, F.P., 1994. Inter individual variations in human liver cytochrome enzymes involved in the oxidation of drugs, carcinogens, toxic chemicals: Studies with liver microsomes of, 30 Japanese, 30 Cauca-sians. J. Pharmac. Expe. Therapy, 270, pp.414-423.

12. Mirsalis, J.C., Tyson, C.K., Steinmetz, K.L., Loh, E.K., Hamilton, C.M., Baleke, J.P. and Spalding, J.W. 1989. Measurement of unscheduled dnasynthesis and s-phase synthesis in rodent hepatocytes following in vivotreatment: Testing of 24 compounds. Environ. Molec, Mutagen., 14 pp.155-164.

13. McGregor, D.B., Brown, A.G., Howgate, S., McBride, D., Riach, C. and Caspary, W.J., 1991. Responses of the 15178 y mouse lymphoma cellforward mutation assay.5.27 coded chemicals. Environmental and Molecular Mutagenesis, 17, pp.196-219.

14. Ma, T., et al., 2020. Hydrolyzed polyacrylamide modified diatomite waste as a novel adsorbent for organic dye removal: Adsorption performance and mechanism studies. Polyhedron, 175, p.114227.

15. Kamal, S. and Ahmed, F.E., 2010. Removal of rhodamine B (a basic dye) and thoron (an acidic dye) from dilute aqueous solutions and wastewater simulants by ion flotation. Water Research, 44, pp.14491461.

16. de Oliveira, R.L., et al., 2012. Assessment of by-products of chlorination and photo electro catalytic chlorination of an azo dye. J. Haz. Materials, 205, pp.1-9.

17. $\mathrm{Wu}, \mathrm{J}$., et al., 2016. Catalytic ozonation of organic pollutants from bio-treated dyeing and finishing wastewater using recycled waste iron shavings as a catalyst: Removal and pathways. Water Research, 92, p.140e148.

18. Bailey, S.E., Plin, T.J., Bricka, R.M. and Adrain, D.D., 1999. A review of potentially low-cost sorbents for heavy metals. Water Research, 33, pp.2469-2479.

19. Urase T. and Kikuta, T., 2005. Separate estimation of adsorption and degradation of pharmaceutical substances and estrogens in the activated sludge process. Water Research, 39, pp.1289-1300.

20. Ozaki, H., 2004. Rejection of Micropollutants by Membrane Filtration. Proceedings of the Regional Symposium on Membrane Science and Technology, Malaysia, Johor.

21. Servos, M., Bennie, R. and Burnisonetal, B.K., 2005. Distribution of estrogens, 17 beta-estradiol and estrone, in Canadian municipal wastewater treatment plants. Science of the Total Environment, 336, pp. $155-170$.

22. Vieno, N., Tuhkanen, T. and Kronberg L., 2006. Removal of pharmaceuticals in drinking water treatment: Effect of chemical coagulation. Environm. Techn., 27, pp.183-192.

23. Westerhoff, P., Yoon, Y. Snyder, S. and Wert, E., 2005. Fate of endocrine-disruptor, pharmaceutical, and personal care product chemicals during simulated drinking water treatment processes. Environmental Science and Technology, 39, pp.66496663.

24. Petrovic, M., Diaz, A., Ventura, F. and Barcel'o, D., 2003. Occurrence and removal of estrogenic short-chain ethoxy nonylphenolic compounds and their halogenated derivatives during drinking water production. Environme. Sci. Techn., 37, pp.4442-4448.

25. Suffet, I.H., Ho, J., Chou, D., Khiari, D. and Mallevialle, J., 1995. Tasteand-Odor Problems Observed During Drinking Water Treatment. in Advances in Taste-and-Odor Treatment Eds., AmericanWater Works Association. 
26. Sugunan, A. and Dutta, J., 2010. Pollution treatment, remediation and sensing. Nanotechn., 2, pp.125-147.

27. Ibhadon, A.O. and Fitzpatrick, P., 1995. Heterogeneous photocatalysis: Recent advances and applications. Catalysts, 3, pp.189-218.

28. Hoffmann, M.R., Martin, S.T. and Choi, W.D.W., 1995. Bahnemann, environmental applications of semiconductor photocatalysis. Chemical Reviews, 95, pp.69-96.

29. Viswanathan, B., 2018. Photocatalytic degradation of dyes: An overview. Current Catalysis, 7, pp.99-121.

30. Khandekar, D.C., et al., 2019. Journal of Environmental Chemical Engineering, 7, p.103433.

31. Ahmed A. Ibrahim, Farid A. Harraz, Houcine Bouzid, Al-Assiri, M.S. and Adel A. Ismaila, 2015. $\mathrm{SnO}_{2}$ doped $\mathrm{ZnO}$ nanostructures for highly efficient photocatalyst. J. Molec. Cataly. A: Chem., 397, pp.19-25.

32. Serr, A., Pip, P., G'omez, E. and Philippe, L., 2020. Efficient magnetic hybrid $\mathrm{ZnO}$-based photocatalysts for visible-light-driven removal of toxic cyanobacteria blooms and cyanotoxins, Applied Catalysis B: Environmental, 268.

33. Jiang, Z., Xiao C., Yin, X., Xu, L., Liu, C. and Wang H., 2020. Facile preparation of a novel $\mathrm{Bi}_{24} \mathrm{O}_{31} \mathrm{Br}_{10} /$ nano- $\mathrm{ZnO}$ composite photocatalyst with enhanced visible light photocatalytic ability. Ceramics International, 46(8), pp.10771-10778.

34. Kuang, M., Zhang, J., Wang, W., Chen, J., Liu, R., Xie, S., Wang, J. and Ji, Z., 2019. Synthesis of octahedral-like $\mathrm{ZnO} / \mathrm{ZnFe}_{2} \mathrm{O}_{4}$ heterojunction photocatalysts with superior photocatalytic activity. Sol. Sta. Sciences, 96, p.105901.

35. Pastor, A., Balbuena, J., Cruz-Yusta, M., Pavlovic, I. and Sánchez, L., 2019. $\mathrm{ZnO}$ on rice husk: A sustainable photocatalyst for urban air purification. Chem. Engin. J., 368, pp.659-667.

36. Hu, K., Li, R., Ye, C., Wang, A., Wei, W., Hu, D., Qiu, R. and Yan, K., 2020. Facile synthesis of Z-scheme composite of $\mathrm{TiO}_{2}$ nanorod/g- $\mathrm{C}_{3} \mathrm{~N}_{4}$ nanosheet efficient for photocatalytic degradation of ciprofloxacin. Journal of Cleaner Production, 253, pp.1200552.

37. Ye, C., Hu, K., Niu, Z., Lu, Y., Zhang, L. and Yan, K., 2019. Controllable synthesis of rhombohedral $\alpha$-Fe(2O), efficient for photocatalytic degradation of bisphenol. A Journal of Water Process Engineering, 27, pp.205-210.

38. Chen, S., Liu, F., Xu, M., Yan, J., Zhang, F., Zhao, W., Zhang, Z., Deng, Z., Yun, J., Chen, R. and Liu, C., 2019. First-principles calculations and experimental investigation on $\mathrm{SnO}_{2} @ \mathrm{ZnO}$ heterojunction photocatalyst with enhanced photocatalytic performance. J. Collo. Interf. Science, 553, pp.613-621.

39. Ma, C., Zhou, Z., Wei, H., Yang, Z., Wang, Z. and Zhang, Y., 2011. Rapid large-scale preparation of $\mathrm{ZnO}$ nanowires for photocatalytic application. Nanoscale Research Letters, 6, p.536.

40. Jingbiao, C., 2012. Zinc oxide nanowires. Materials Characterization, 64, pp.43-55.

41. Chandrasekhar, P.S., Ashish Dubey and Qiao, Q., 2020. High efficiency perovskite solar cells using nitrogen-doped graphene/ZnO nanorod composite as an electron transport layer. Solar Energy, 197, pp.78-83.

42. Peng, Y., et al., 2019. Achieving high-resolution pressure mapping via flexible $\mathrm{GaN} / \mathrm{ZnO}$ nanowire LEDs array by piezo-phototronic effect. Nano Energy, 58, pp.633-640.

43. Ovando-Medina, V.M., Dector, A., Antonio-Carmonac, D., Romero, G. and Martínez-Gutiérrez, H., 2019. A new type of air-breathing photo-microfluidic fuel cell based on $\mathrm{ZnO} / \mathrm{Au}$ using human blood as energy source, International Journal of Hydrogen Energy, 44, pp.31423-31433.

44. Sarma, B. and Sarma, B.K., 2018. Role of residual stress and texture of $\mathrm{ZnO}$ nanocrystals on electrooptical properties of $\mathrm{ZnO} / \mathrm{Ag} / \mathrm{ZnO}$ multilayer transparent conductors. Journal of Alloys and Compounds, 734, pp.210-219.
45. Kadam, A.N., et al., 2017. Morphological evolution of $\mathrm{Cu}$ doped $\mathrm{ZnO}$ for enhancement of photocatalytic activity. Journal of Alloys and Compounds, 710, pp.102-113.

46. Ansari, S.A., Khan, M.M., Kalathil, S., Nisar, A., Leea, J. and Cho, M.H., 2013. Oxygen vacancy induced band gap narrowing of $\mathrm{ZnO}$ nanostructures by an electrochemically active biofilm. Nanoscale, 5 , pp.9238-9246.

47. Wanga, D., Wang, S., Li, B., Zhang, Z. and Zhang, Q., 2019. Tunable band gap of $\mathrm{NV}$ Co-doped $\mathrm{Ca}: \mathrm{TiO}_{2} \mathrm{~B}\left(\mathrm{CaTi}_{5} \mathrm{O}_{11}\right)$ for visiblelight photocatalysis. International Journal of Hydrogen Energy, 44, pp.4716-4723.

48. Singh, A.V., Mehra, R.M., Wakahara, A. and Yoshida, A., 2004. Doping mechanism in $\mathrm{Al}$ doped $\mathrm{ZnO}$ films. Journal of Applied Physics, 95, pp.3640-3653.

49. Tadatsugu, M., Takashi, Y. and Toshihiro, M., 2000. Highly transparent and conductive rare earth-doped $\mathrm{ZnO}$ thin films prepared by magnetron sputtering. Thin Solid Films, 366, pp.63-68.

50. Ravinder, K., Singh, A.V. and Mehra, R.M., 2005. Structural electrical and optical properties of sol-gel derived yttrium doped $\mathrm{ZnO}$ films. Phys Status Solidi, 206, pp.1053-1059.

51. Norberg, N.S., Kittilstved, K.R., Amonette, J.E., Kukkadapu, R.K., Schwartz, D.A. and Gamelin, D.R., 2004. Synthesis of colloidal $\mathrm{Mn}_{2+}: \mathrm{ZnO}$ quantum dots and high-Tc ferromagnetic nanocrystalline thin films. Journal of the American Chemical Society, 126, pp.93879398.

52. Bhatti, M.A., et al., 2019. Efficient photo catalysts based on silver doped $\mathrm{ZnO}$ nanorods for the photodegradation of methyl orange. Ceramics International, 45, pp.23289-23297.

53. Shah, A.A., Bhatti, M.A., Tahira, A., Chandio, A.D., Channa, I.A., Sahito, A.G., Ebrahim, S., Willander, M., Nur, O. and Ibupoto, Z.H., 2019. Facile synthesis of copper doped $\mathrm{ZnO}$ nanorods for the efficient photo degradation of methylene blue and methyl orange. Ceramics International, 46(8), pp.9997-10005.

54. Kabongo, G.L., Mhlongo, G.H., Malwela, T., Mothudi, B.M., Hillie, K.T. and Dhlamini, M.S., 2014. Microstructural and photoluminescence properties of sol-gel derived $\mathrm{Tb} 3+$ doped $\mathrm{ZnO}$ nanocrystals. J. Alloys Compd., 591, pp.156-163.

55. Lommens, P., Lambert, K., Loncke, F., De Muynck, D., Balkan, T., Vanhaecke, F., Vrielinck, H., Callens, F. and Hens, Z., 2008. The growth of $\mathrm{Co}: \mathrm{ZnO} / \mathrm{ZnO}$ core/shell colloidal quantum dots: Changes in nanocrystal size, concentration and dopant coordination. ChemPhysChem, 9, pp.484-491.

56. Lorke, M., Frauenheim, T. and da Rosa, A.L., 2016. Manybody electronic structure calculations of Eu-doped $\mathrm{ZnO}$. Phys. Rev. B, 93.

57. Jeon, H.J., Maeng, W.J. and Park, J.S., 2014. Effect of Al concentration on the electrical characteristics of solution-processed $\mathrm{Al}$ doped $\mathrm{ZnSnO}$ thin film transistors. Ceram. Int., 40, pp.87698774.

58. Ntwaeaborwa, O.M. and Holloway, P., 2005. Enhanced photoluminescence of $\mathrm{Ce} 3+$ induced by an energy transfer from $\mathrm{ZnO}$ nanoparticles encapsulated in $\mathrm{SiO}_{2}$. Nanotechn, 16, p.865.

59. Khataee, A., Soltani, R.D., Karimi, A. and Joo, S.W., 2015. Sonocatalytic degradation of a textile dye over Gd-doped $\mathrm{ZnO}$ nanoparticles synthesized through sonochemical process. Ultrason. Sonochem., 23, pp.219-230.

60. Sun, L.-W., Shi, H.Q., Li, W.N., Xiao, H.M., Fu, S.Y., Cao, X.Z. and Li, Z.X., 2012. Lanthanum-doped $\mathrm{ZnO}$ quantum dots with greatly enhanced fluorescent quantum yield. J. Mater. Chem., 22, pp.82218227.

61. Saharan, P., Chaudhary, G.R., Lata, S., Mehta, S.K. and Mor, S., 2015. Ultra-fast and effective treatment of dyes from water with the synergistic effect of $\mathrm{Ni}$ doped $\mathrm{ZnO}$ nanoparticles and ultrasonication. Ultrason. Sonochem., 22, pp.317-325.

62. Mokhles, A.G. and Vaez-Zadeh, M., 2016. A numerical study on magnetic and structural properties of Ni-doped $\mathrm{ZnO}$ nanoparticles at 
extremely low temperatures. J. Supercond. Nov. Magn., 29, pp.12951302.

63. Beura, R., Pachaiappan, R. and Thangadurai, P., 2018. A detailed study on $\mathrm{Sn} 4+$ doped $\mathrm{ZnO}$ for enhanced photocatalytic degradation. App. Surf. Science, 433, pp.887-898.

64. Beura, R. and Thangadurai P., 2018. Effect of $\mathrm{Sn}$ doping in $\mathrm{ZnO}$ on the photocatalytic activity of $\mathrm{ZnO}-G r a p h e n e$ nanocomposite with improved activity. J. Environm. Chem. Engin, 6, pp.50875100.

65. Jia, X. Fan, H., Mohammad Afzaal, Wu, X. and O'Brien, P., 2011. Solid state synthesis of tin-doped $\mathrm{ZnO}$ at room temperature: Characterization and its enhanced gas sensing and photocatalytic properties. Journal of Hazardous Materials, 193, pp.194-199.

Received: 22 April 2020. Accepted: 22 May 2020. 